\title{
Histrionic Personality Disorder
}

National Cancer Institute

\section{Source}

National Cancer Institute. Histrionic Personality Disorder. NCI Thesaurus. Code C92634.

A disorder characterized by an enduring pattern of excessively intense and superficial

emotionality, attention seeking behavior, seductive appearance and speech, self

dramatization and/or theatrical behavior. 